\title{
SENI REJUNG SEBAGAI BAHAN MATERI PEMBELAJARAN MUATAN LOKAL PROVINSI SUMATERA SELATAN
}

\author{
Oleh: Fadhilah Hidayatullah \\ (Dosen Universitas PGRI Palembang) \\ Email: fadhilahhidayatullah@gmail.com
}

\begin{abstract}
Abstrak
Tujuan penulisan artikel ini adalah untuk mendeskripsikan hasil penelitian tentang pengetahuan dan wawasan seni rejung. Hasil penelitiannya menghasilkan susunan materi yang dapat diterapkan pada pembelajaran muatan lokal provinsi Sumatera Selatan. Karena terdapat nilai-nilai kearifan lokal yang patut dipelajari oleh peserta didik. Adapun materi yang dibahas pada artikel ini adalah teknik menembangkan seni rejung, cara pembawaan seni rejung, syair seni rejung, dan irama pada seni rejung.
\end{abstract}

Kata Kunci: Seni Rejung, Materi Pembelajaran, Muatan Lokal

\section{REJUNG ARTS AS LEARNING MATERIALS LOCAL MUATAN PROVINCE OF SOUTH SUMATERA}

\begin{abstract}
The purpose of writing this article is to describe the results of research on the knowledge and insights of rejung art. The results of his research produced a composition of material that can be applied to the learning of local content in the province of South Sumatra. Because there are values of local wisdom that should be learned by students. The material discussed in this article is the technique of developing rejung art, ways of carrying rejung art, rejung art poetry, and rhythm in rejung art.
\end{abstract}

Keywords: Rejung Art, Learning Material, Local Content

\section{A. PENDAHULUAN}

Rejung merupakan kesenian yang berkembang pada seputaran wilayah rumpun Besemah. Kesenian ini dinyanyikan menggunakan syair pantun dalam bahasa dealek semende. Adapun ciri dari bahasa yang digunakan yakni lebih identik pada pelafalan huruf "E" seperti masyarakat melayu pada umumnya. Hal tersebut menjadi karakter budaya pada suku atau etnik tersebut, yang menjadi 
kekayaan budaya lokal, serta memiliki nilai kearifan lokal yang terdapat pada isi dari masing-masing pantunnya.

Kesenian rejung juga merupakan salah satu materi muatan lokal, hal tersebut dibuktikan pada peraturan gubernur tahun 2015, terkait dengan susunan materi muatan lokal provinsi Sumatera Selatan. Hal tersebut dapat dijadikan sebagai dasar dan pedoman untuk menyusun kurikulum muatan lokal Sumatera Selatan. Sehingga kesenian rejung mempunyai kurikulum dengan susunan materi tersendiri.

Kurikulum muatan lokal disusun untuk mewujudkan pelestarian, pengembangan, serta memberikan keterampilan bagi para peserta didik sebagai pewaris budaya. Untuk melaksanakan kurikulum muatan lokal mata pelajaran, maka ditetapkan silabus muatan lokal dengan acuan pembelajaran dalam proses belajar mengajar. Keberadaan mata pelajaran muatan lokal yang ada di provinsi Sumatera Selatan saat ini baru berpedoman pada peraturan gubernur provinsi Sumatera Selatan terkait dengan materi muatan lokal yang terdapat di setiap daerah provinsi Sumatera Selatan. Karena secara khusus belum adanya kurikulum muatan lokal untuk wilayah provinsi Sumatera Selatan.

Salah satu daerah yang memiliki kesenian budaya lokal dengan nama “rejung” yakni kabupaten OKU Selatan. Keberadaannya saat ini mulai dilupakan dan kurangnya apresiasi dari generasi muda. Oleh karena itu, sudah sepatutnya sekolah menerapkannya dalam pembelajaran muatan lokal, agar generasi muda dapat mengenali dan tertanam rasa memiliki terhadap kesenian tersebut.

Sehubungan dengan hal diatas, maka penulis melakukan penelitian dengan mendeskripsikan hasil penelitian tentang "Materi seni rejung untuk pembelajaran muatan lokal". Alasan dilakukan penelitian ini adalah untuk memberikan gambaran materi pembelajaran muatan lokal seni rejung, sehingga mudah untuk menerapkan pada proses pembelajarannya. 


\section{B. METODOLOGI PENELITIAN}

Metode yang diterapkan pada penelitian ini adalah deskreptif kualitatif. Metode deskriptif adalah "suatu metode dalam pencarian fakta status kelompok manusia, suatu objek, suatu kondisi, suatu sistem pemikiran ataupun suatu peristiwa pada masa sekarang dengan interprestasi yang tepat (Sudarmayanti, dkk., 2002:33)."

Melalui pendekatan tersebut, akan disajikan data dari hasil kegiatan observasi dan wawancara. Senada dengan yang dikemukakan oleh Poham (dalam Prastowo, 2011:208) bahwa "teknik pengumpulan data adalah cara yang di pakai untuk mengumpulkan informasi." Kemudian juga sebagai langkah yang paling strategis dalam penelitian karena tujuan utama penelitian adalah mendapatkan data (Sugiyono dalam Prastowo, 2011:208).

Oleh karena itu, data observasi di peroleh melalui kegiatan pengamatan langsung pada kesenian rejung. Dimulai dari melihat para kelompok seniman yang ada di daerah pemilik maupun daerah persebaran. Selain itu dilakukan dengan cara mengelompokan berbagai lagu melalui bentuk MP3 yang diperoleh dari pengamatan (melihat dan mendengarkan) dari akun sosial media (youtube, facebook, dan lainnya). Dari hal tersebutlah sehingga data yang berhubungan dengan materi pada seni rejung akan dianalisa menggunakan metode deskriptif kualitatif, akan diurai dan di deskripsikan berdasarkan pengamatan dan wawancara yang telah dilakukan.

\section{HASIL PENELITIAN DAN PEMBAHASAN}

Sebagai salah satu bahan materi pada pembelajaran seni rejung adalah audio seni rejung. Didalam lagu terdapat syair dan irama, syair yang berbentuk pantun, sedangkan irama terdapat susunan nada yang terpola. Namun, segala hal informasi yang terkait dengan pengetahuan seni rejung merupakan data yang penting untuk diuraikan dalam penelitian ini. Maka dari itu, akan dideskripsikan hasil yang diperoleh dari lapangan. 


\section{a. Wawasan umum seni rejung}

Kata "rejung" berasal dari bahasa daerah etnik Semende. Berdasarkan pandangan para tokoh masyarakat dan seniman setempat yang ada didaerah Semende (desa Tanjung Bulan, kecamatan Pulau Beringin, OKU Selatan, Sumatera Selatan), rejung mempunyai makna "pantun". Namun tentunya pantunnya adat Semende, yang menggunakan bahasa dan dialek rurah Semende pula.

Masyarakat Semende umumnya mengenali rejung dengan kata "berejung" yang dimaknai dengan menunjukkan kegiatan yang sedang menembangkan pantun Semende. Dengan demikian dapat disimpulkan bahwa kesenian rejung merupakan salah satu kesenian daerah etnik Semende yang dipayungi oleh pemerintah provinsi Sumatera Selatan. Kesenian ini dinyanyikan melalui penembangan pantun Semende, diiringi beberapa alat musik instrumen, yang sering digunakan adalah alat musik gitar.

Seni rejung disajikan oleh seniman yang usia nya di atas 40 tahun. Namun tentunya tidak dibatasi dari segi umur. Artinya siapa saja yang ingin menyajikan kesenian tersebut dapat dilantunkan. Kesenian ini dilakukan oleh orang-orang yang sudah berusia lanjutan, disebabkan pentransformasiannya hanya dilakukan melalui pendidikan informal. Alat musik pengiring yang sering dipakai saat ini adalah gitar, biola, dan gambus. Masing-masing mempunyai nama tersendiri yang digunakan untuk penyebuatan nama pada alat musik tersebut. Maka pada penyebutan alat musik gitar adalah itar, biola disebut dengan piul, sedangkan penyebutan gambus tidak berubah. Bentuk penyajian dari seni rejung tersebut dapat dilihat pada tabel berikut.

Tabel 1 Penyajian Seni Rejung

\begin{tabular}{|c|c|c|c|c|c|}
\hline \multicolumn{2}{|c|}{ TAHAPAN } & \multicolumn{2}{c|}{ BENTUK PENYAJIAN } & \multicolumn{2}{c|}{ KETERANGAN } \\
\hline Awal & Pembuka & $\begin{array}{c}\text { Instrumen Alat } \\
\text { Musik }\end{array}$ & $\begin{array}{c}\text { Gitar 1, gitar 2, } \\
\text { gambus, biola. }\end{array}$ & $\begin{array}{c}\text { Tanpa } \\
\text { Pantun }\end{array}$ & Melodi A \\
\hline Inti & $\begin{array}{c}\text { Memasuki lagu baris satu } \\
\text { dan dua diiringi dengan } \\
\text { musik iringan }\end{array}$ & $\begin{array}{c}\text { Vokal dan } \\
\text { Instrumen Alat } \\
\text { Musik }\end{array}$ & $\begin{array}{c}\text { Tembang } \\
\text { Pantun, gitar 1, } \\
\text { gitar 2, gambus, } \\
\text { biola. }\end{array}$ & $\begin{array}{c}\text { Pantun } \\
\text { Baris Satu }\end{array}$ & Melodi A \\
\cline { 4 - 6 } & $\begin{array}{c}\text { Pantun } \\
\text { Baris Dua }\end{array}$ & Melodi B \\
\hline
\end{tabular}




\begin{tabular}{|c|c|c|c|c|c|}
\hline \multicolumn{2}{|r|}{ TAHAPAN } & \multicolumn{2}{|c|}{ BENTUK PENYAJIAN } & \multicolumn{2}{|c|}{ KETERANGAN } \\
\hline & $\begin{array}{c}\text { Masa peralihan lagu, } \\
\text { setelah baris dua, atau } \\
\text { sebelum memasuki baris } \\
\text { ketiga }\end{array}$ & $\begin{array}{c}\text { Instrumen Alat } \\
\text { Musik }\end{array}$ & $\begin{array}{l}\text { Gitar 1, gitar } 2 \text {, } \\
\text { gambus, biola. }\end{array}$ & $\begin{array}{l}\text { Tanpa } \\
\text { Pantun }\end{array}$ & $\begin{array}{l}\text { Melodi A } \\
\text { dan } \\
\text { Campuran }\end{array}$ \\
\hline & \multirow{2}{*}{$\begin{array}{c}\text { Melanjutkan lagu pada } \\
\text { baris ketiga dan empat } \\
\text { setelah instrumen } \\
\text { peralihan }\end{array}$} & \multirow{2}{*}{$\begin{array}{c}\text { Vokal dan } \\
\text { Instrumen Alat } \\
\text { Musik }\end{array}$} & \multirow{2}{*}{$\begin{array}{c}\text { Tembang } \\
\text { Pantun, gitar 1, } \\
\text { gitar 2, gambus, } \\
\text { biola. }\end{array}$} & $\begin{array}{c}\text { Pantun } \\
\text { Baris Tiga }\end{array}$ & Melodi A \\
\hline & & & & $\begin{array}{c}\text { Pantun } \\
\text { Baris Empat }\end{array}$ & Melodi B \\
\hline Penutup & Penutup & $\begin{array}{c}\text { Instrumen Alat } \\
\text { Musik }\end{array}$ & $\begin{array}{l}\text { Gitar 1, gitar } 2 \text {, } \\
\text { gambus, biola. }\end{array}$ & $\begin{array}{l}\text { Tanpa } \\
\text { Pantun }\end{array}$ & $\begin{array}{l}\text { Melodi A } \\
\text { dan } \\
\text { Campuran }\end{array}$ \\
\hline
\end{tabular}

Kesenian rejung dilakukan pada acara-acara syukuran, panen hasil kebun dan sawah, serta perkenalan bujang gadis yang digunakan sebagai media komunikasi antara muda-mudi. Namun tentunya saat ini fungsi dan perannya sudah mengalami pergeseran, sehingga menjadi hiburan semata yang dilakukan sesuai dengan kondisi yang diinginkan para pelaku atau seniman diwilayah itu. Peran dan fungsi dari kesenian rejung, diklasifikasikan menjadi dua macam, yakni peran dan fungsi zaman dahulu dan saat ini. Zaman dahulu, kesenian rejung berfungsi sebagai media komunikasi, tuntunan dan metode pengajaran, serta ekspresi jiwa. Sedangkan saat ini, sebagai media pendidikan, dan hiburan.

\section{b. Wawasan Khusus Seni Rejung}

Untuk memahami tema pada syair seni rejung, diperlukan konsentrasi. Karena bahasa yang didengarkan, kadangkala masih bersifat asing. Maka dari itu, memerlukan konsentrasi yang tinggi. Masing-masing contoh syair adalah sebagai berikut.

Syair dalam bahasa etnik Semende

Baris se : Gendule tumbuh dilembak

Baris due : Dibawah batang la kayu rimbun

Baris tige : Makmane liku nak tunak

Baris empat : Idup di buang la karang tampun

Baris se : Banyak-banyak kayu anak

Baris due : Cuman sebatang banyak dahannye

Baris tige : Banyak-banyak la anak bapak

Baris empat : Aku lah suhang idup sengsare

Barisse : Bawah duhuk belading kecik

Baris due :Oi pisau ye besak kandik ke utan 
Seni Rejung sebagai.... (Fadhilah Hidayatullah)

Baris tige : Nuntut ilmu empung gi kecik

Baris empat : Oi ame la besak banyak rupuan

Setelah wawasan umum dan khusus telah terurai, maka peneliti menyimpulkan bahwa rejung selalu dinyanyikan menggunakan syair yang berbentuk pantun dalam bahasa daerah semende, atau dinyanyikan berdasarkan karakter daerahnya. Maka materi yang dapat disusun untuk pembelajaran muatan lokal adalah jenis rejung yang pernah berkembang; kumpulan pantun yang familiar; pelaku dan penyanyi yang mempopulerkan sampai pada perkembangannya.

Adapun materi tersebut dapat diklasifikasikan menjadi tiga kelompok, yakni sebagai berikut.

1. Pelafalan Huruf-huruf Inti pada karakter bahasa Semende

2. Memahami makna tersirat yang disampaikan melalui pantun

3. Menyanyikan/menembangkan

Ketiga tahapan tersebut dapat dijadikan sebagai langkah atau sintak pembelajaran pada kesenian rejung. Namun dalam hal ini, sudut pandang pada muatan lokal yang ada pada seni rejung.

\section{PEMBAHASAN}

Berdasarkan Peraturan Gubernur Sumatera Selatan tentang materi muatan lokal di kabupaten OKU Selatan, tahun 2015; bahwa seni rejung merupakan salah satu materi yang dimuat melalui kelompok bidang lingkungan budaya. Adapun alasan materi tersebut perlu dimuat dalam kurikulum adalah karena layak dipelajari untuk memberikan pengetahuan kepada peserta didik akan kekayaan budaya daerah untuk dilestarikan dan dikembangkan, serta mendukung kepariwisataan.

\section{a. Konsep Materi Kesenian Rejung Secara Umum}

\section{1) Pelafalan Huruf-huruf Inti pada karakter bahasa Semende}

Pelafalan pada masyarakat semende berbeda dengan masyarakat pada umumnya. Sebagai perbandingan dengan pelafalan pada Bahasa Indonesia yang 
lebih mengenal huruf $\mathrm{O}, \mathrm{U}, \mathrm{E}, \mathrm{I}$, dan lain sebagainya. Kalau pada kesenian ini, tidak ada pelafalan huruf $\mathrm{O}$, E layaknya pelafalan pada Bahasa Indonesia. Pelafalan tersebut dapat jelas dan terlihat perbedaannya setelah dipraktekkan secara langsung. Karena melalui penjelasan kalimat tidak akan dapat diketahui perbedaannya sampai ke detealnya. Maka untuk memahami karakter pada bahasa Semende yang digunakan pada syair atau pantun rejung ini, haruslah dipraktikkan secara langsung.

\section{2) Menyanyikan atau menembangkan}

Melalui kegiatan ini, peserta didik yang mengikuti pembelajaran rejung haruslah berpedoman pada dasar kurikulum muatan lokal yang diatur melalui peraturan gubernur sumatera selatan yakni bertujuan untuk memberikan pengetahuan kepada peserta didik akan kekayaan budaya daerah untuk dilestarikan dan dikembangkan, serta mendukung kepariwisataan. Oleh karena itu, melalui penerapan pembelajarannya, maka akan ditampilkan dengan cara mengekspresikan kesenian rejung dalam bentuk tembang (nyanyian).

Melalui tujuan pergub tersebut, maka harus dilestarikan dengan cara ikut berperan langsung dalam mempraktikan dengan cara menembangkan. Setelah itu patut untuk dikembangkan melalui kondisi perkembangan teknologi saat ini. Tepat rasanya bahwa keseniann ini sudah menyebar di berbagai akun sosial media. Selain itu pula tepat rasanya kalau sudah disusun kedalam tutorial seni rejung dalam pembelajaran muatan lokal. Dengan demikian, siapapun gurunya yang latar belakangnya lahir di luar daerah pusat daerah tersebut, akan tetap dapat beradaptasi untuk mngajarkannya baik dari pengetahuannya maupun pada tingkat psikomotoriknya atau bakatnya.

\section{3) Memahami makna tersirat yang disampaikan melalui pantun}

Pantun yang pernah berkembang pada masyarakat umum, biasanya tidak mudah untuk dipahami. Mengapa dikatakan demikian? Karena setiap kata yang diucapakan merupakan sebagai perumpamaan-perumpamaan. Namun tidak berlaku pada semua pantun. Ada beberapa pantun yang masih sulit untuk 
diterjemah ke Bahasa Indonesia secara langsung. Namun ada pula pantun yang mudah untuk di transkripsikan ke dalam Bahasa Indonesia. Oleh karena itu, tingkatan-tingkatan Bahasa yang digunakan di dalam pantun tersebut sangatlah bernilai filosofis yang menggambarkan kehidupan. Sumardjo (2006:164), mengutarakan dalam bukunya "perhatikan baris pertama dan kedua, keduanya merupakan gambaran alam. Itulah dunia makrokosmos. Baris ketiga dan keempat merupakan gambaran kehidupan manusia. Makrokosmos atau alam itu gambaran mikrokosmos juga, sehingga muncul pepatah: Alam terkembang menjadi guru. Alam adalah guru manusia, karena alam itu sendiri juga hidup seperti manusia. Begitu alam, begitu manusia."

Sehingga dapat disimpulkan bahwa pada baris pantun mengandung makna. Baris pertama dan kedua mengandung gambaran alam, sedangkan baris tiga dan empat menggambarkan kehidupan manusia. Alam digambarkan pada kehidupan makrokosmos, sedangkan kehidupan manusia digambarkan pada mikrokosmos, namun kehidupan makrokosmos atau alam tadi merupakan gambaran dari kehidupan mikrokosmos pula. Artinya alam dan manusia saling berhubungan. Manusia ditentukan oleh alam, namun manusia kadang kala menentukan alam, seperti terjadi pada kehidupan zaman sebelum dan setelah moderen.

Melalui syair-syair tersebut banyak pula yang meratapi nasib dari perjalanan hidup. Baik kehidupan pribadi maupun kehidupan orang lain atau keluarganya. Adapula yang menyisipkan makna tentang adab, tatakrama, maupun cara pribadi untuk berkehidupan sosial pada umumnya. Seperti yang diungkap oleh Kordin, Ahmad (2020) yakni "besindat, besendi, besundi, besingkuh, bemalu, serta betungguan". Adapun maksud dari istilah tersebut, secara umum dapat dijelaskan sebagai berikut. Istilah "Besindat, besendi, besundi, besingkuh" merupakan segala sesuatu itu harus ada batas-batas tertentu. Sedangkan "bemalu, betungguan" merupakan ucapan yang harus diiringi dengan kenyataan atau dengan istilah daerah setempatnya adalah tuape ye lah di katekah ndak taruhi/ ditaruhi (Kordin, Ahmad., wawancara, 01 Mei 2020, pukul 13.00 s/d selesai). 
Itulah semboyan suku atau etnik Semende yang membawa kepribadian dari masyarakat tersebut tersohor di dunia sosial lainnya. Sehingga masyarakat tersebut dikenal dengan kepribadian yang arif dan bijaksana dari segala macam perlakuannya. Hal-hal tersebut yang seharusnya digalakkan di dalam pembelajaran anak dimulai dari sedini mungkin, agar kelak anak dapat mengenal karakter dan keperibadian yang baik. Sehingga karakter bangsa akan baik pula, karena generasi penerusnya sudah menanamkan dari sedini mungkin.

Semboyan yang harus dijunjung tinggi tersebut, harus menjadi materi dari muatan lokal, yang dapat dipelajari dari bahasa yang digunakan. Materi tersebut sangat dekat dengan norma atau etika. Maka sangat kompleks bahwa melalui kesenian rejung ini dapat dipelajari berbagai macam untuk menuju jati diri yang sesungguhnya. Entah siapa yang menciptakan syair-syair atau pantun-pantun pada kesenian rejung ini, namun setelah berkembangnya kesenian tersebut pantun tersebut sudah tidak asing lagi di telinga masyarakat sekitar.

\section{b. Susunan Materi Kesenian Rejung untuk Pembelajaran Muatan Lokal}

Setelah konsep materi yang telah diuraikan sebelumnya, yakni; pelafalan huruf inti pada karakter bahasa Semende; berperan langsung dalam mengekspresikan dalam menembangkan rejung; serta memahami makna yang tersirat pada pantun. Maka akan dibahas lebih mendalam melalui materi pembelajaran yang bermuara pada muatan lokal.

Abidin (2014:263) mengemukakan bahwa "materi pembelajaran sebagai program yang di susun guru untuk mengembangkan pengetahuan, keterampilan, dan sikap di susun guru untuk mengembangkan pengetahuan, keterampilan, dan sikap positif terhadap pembelajaran yang diturunkan dari kurikulum yang berlaku." Adapun materi yang disusun tersebut adalah teknik menembangkan seni rejung, cara pembawaan seni rejung, syair seni rejung, serta irama seni rejung. 


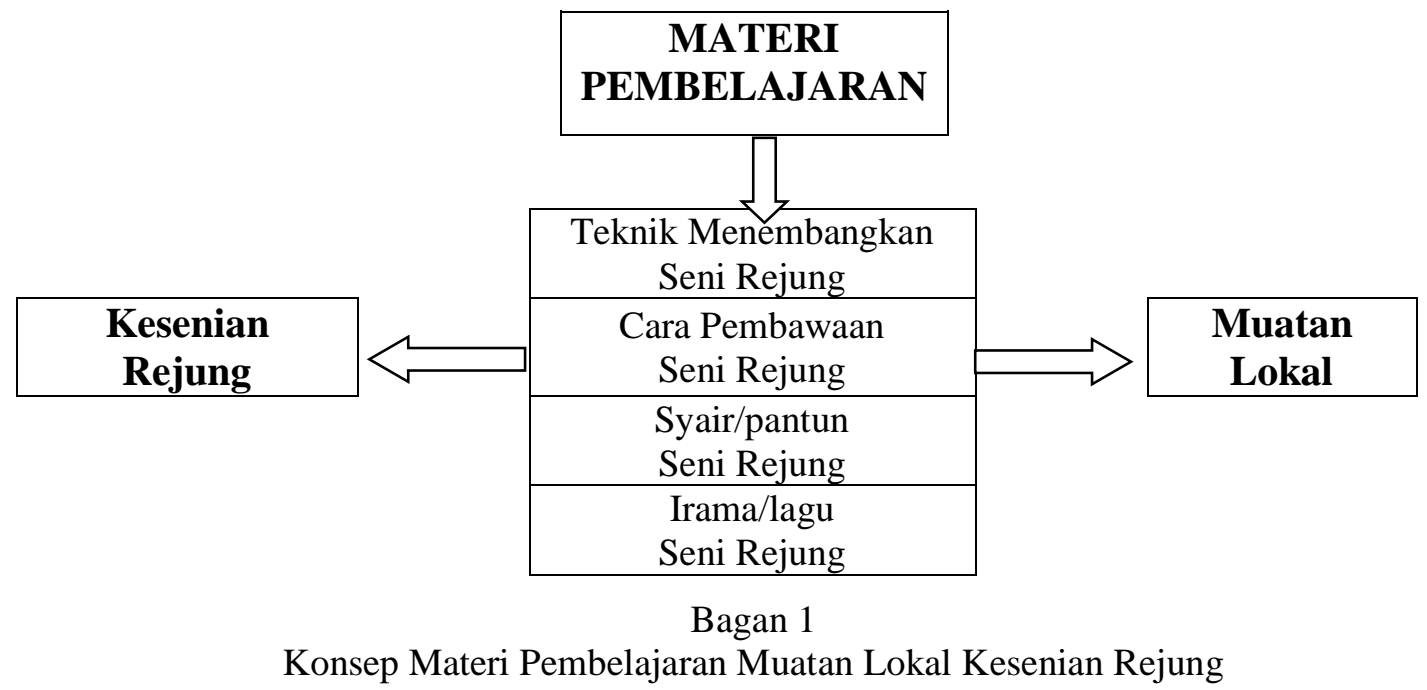

\section{1) Teknik menembangkan seni rejung}

\section{a) Care duduk (Cara Duduk)}

Cara duduk pada seni rejung tidak ada ketentuan bakunya. Namun masyarakatnya memandang duduk yang paling sopan adalah bersilapanggung. Dengan demikian, para senimanpun melakukan hal yang sama yakni dengan duduk silapanggung (duduk bersila) saat berejung.

Posisi pelaku saat menembangkan rejung yakni duduk bersila dengan posisi badan tegak lurus. Sesuai dengan perkembangan zaman, maka saat ini cara duduknya dapat dilakukan berbagai cara, dimulai duduk dikursi, bahkan berdiri karena dilakukan dipanggung. Begitupun dengan para pengiring alat musik instrumen, mengikuti dari penembangnnya yang disesuaikan dengan kondisi yang ada.

\section{b) Kenjun (Penyajian Vokal)}

Kesenian rejung merupakan seni vokal yang mempunyai ciri khas pada kenjun dan syair yang menggunakan dialek etnik semende (Hidayatullah, 2015:87). Vokal yang dilakukan dalam kesenian rejung ini terdapat beberapa penyajian yang berbeda. ada yang menyajikan dengan cara menyanyikan lantang, dan adapula yang menyanyikan dengan cara mendayu-dayu. Teknik yang dilakukan dengan cara terang dan lantang tersebut, vokal yang dikelurkan 
tentunya menyanyikan kenjun dan syair yang dekat dengan kesan meriah atau gembira.

Apabila membawakan kenjun dan syair yang bersifat sedih atau meringit, maka suara yang mendayu-dayulah yang digunakan. Vokal yang mendayu-dayu tersebut, menitikberatkan pada rasa yang paling utama, namun tidak memperhatikan dan mengutamakan teknik vokalnya.

\section{c) Penyebutan kate-kate (Artikulasi)}

Pengucapan huruf dalam pelantunan kesenian rejung, tentunya berbeda dengan layaknya bernyanyi pop Indonesia atau yang lainnya. Penyebab terjadinya perbedaan yakni pada dialek yang menggunakan bahasa daerah yakni etnik semende. Pengucapan huruf /E/ (dialek Indonesia), intonasinya menjadi /ê/ (yang berintonasi melayu). Lalu huruf $/ O /$ lebih tekanannya menjadi huruf $/ u /$. Akhiran huruf /A/ maka akan mendekati kata /akh/. Artikulasi dalam pelantunan kesenian rejung terdapat ciri dan karakter pada penekanan huruf /E/, /I/, dan /U/, yang dapat digunakan pada awal, tengah, akhiran, serta campuran pada suku kata.

Tabel 2 Artikulasi Seni Rejung

\begin{tabular}{|c|c|c|c|c|}
\hline \multirow{2}{*}{ HURUF } & \multicolumn{4}{|c|}{ PENGGUNAAN SUKU KATA } \\
\hline & Awal & Tengah & Akhir & Campuran \\
\hline \multirow{2}{*}{ E } & $\underline{E}$ Empuk & Ilẹmu & Mane & Kemane \\
\hline & Walaupun & Ilmu & Mana & Kemana \\
\hline \multirow{2}{*}{ I } & Ilemu & Tehingat & Mati; Janji & Ditimpe ; Digiring \\
\hline & Ilmu & Teringat & Mati; janji & Ditimpa; digiring \\
\hline \multirow{2}{*}{$\mathrm{U}$} & Umpame & $N d \boldsymbol{u} n$ & Ilému & Umur \\
\hline & Contoh & "Kata awalan" & Ilmu & Usia \\
\hline
\end{tabular}

\section{2) Cara Pembawaan Kesenian Rejung}

Cara pembawaan kesenian rejung, dapat dilakukan dengan improvisasi dan ornamen, yang didukung oleh sensitivitas rasa musik. Sehingga komponen tesrsebut dapat disajikan dengan indah. Improvisasi terjadi pada akhir baris, terdapat pada setiap pergantian nafas atau frasa. Improvisasi, terdapat beragam warna suara sesuai dengan karakter setiap penyaji atau pelakunya. 
Begitupun dengan alat instrumen yang mengiringi dapat terjadi improvisasi pada setiap pergantian frasa, bahkan lebih panjang jumlah biramanya. Ornamen dapat dilihat pada akhir baris, atau pergantian nafas selalu ada cengkok yang sangat jelas, dikaitkan dengan komunikasi yang disampaikan adalah sangat berhubungan sekali dengan teks syair yang terdapat pada teks rejung. Namun komunikasi tersebut akan berjalan dengan indah apabila diikuti dengan cengkok yang khas dan indah tersebut. Kemudian pada cengkok tersebut terkomunikasi dari penegasan kalimat serta makna yang disampaikan.

\section{3) Syair lagu seni rejung ringit}

Seni rejung terdapat syair yang berbentuk pantun, mirip dengan pantun melayu, bersajak dan berbaris empat, dengan sajak AB AB (Fang, 2011: 556). Pantun yang digunakan berbahasa daerah etnik Semende. Syair dalam seni rejung terkandung pesan yang disampaikan. Pesan tersebut berupa; amanat dan nasihat, jenaka, agama/hukum, serta sedih. Syair yang berbentuk pantun ini, terdiri atas empat baris, dengan jenis A-A-B-B; A-A-A-A; atau A-B-A-B. Namun yang sering digunakan dalam syair seni rejung adalah berjenis A-B-A-B. Dengan demikian syair tersebut ditembangkan sesuai dengan jenis irama melodi yang digunakan. Maka dari itu contoh syair seni rejung yakni sebagai berikut.

Syair dalam bahasa daerah etnik Semende

Baris se : : Kebile pandan ding la dikkah ringkih

Baris due : :Tumbuh dik ade dingku malang bejunjungan

Baris tige : Kebile badan ding la dik kah sedih

Baris empat : Idupku belum dingku malang bejunjungan

Syair dalam bahasa Indonesia

Baris satu : Bilakah pandan, dik, takkan indah

Baris dua : Tumbuh tiada, adikku sayang, berjunjungan

Baris tiga : Bilakah badan, dik, takkan sedih

Baris empat : Hidupku belum, adikku sayang, bertumpangan 


\section{4) Irama seni rejung ringit}

Irama dalam seni rejung terdiri atas dua bagian, yakni irama "A" dan "B". Irama " $A$ " terdapat disetiap baris ganjil yakni satu dan tiga, sedangkan irama "B" selalu digunakan disetiap baris genap yaitu dua dan empat. Dengan demikian, apabila menyanyikan seni rejung baris satu dan dua, maka sudah mewakili dari semua jenis irama.

Baris Ganjil (satu dan tiga)

$$
\begin{aligned}
& \begin{array}{llllllllllllllllll}
000 & 53 & 3 & \ldots & \overline{03} & 3 & \overline{3} 3 & 3 & \overline{2} & 1 & \ldots & \overline{03} & 2 & \overline{12} & 3 & .2 & 1 & \ldots
\end{array}
\end{aligned}
$$

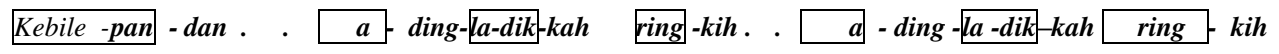

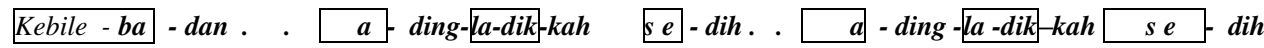

Baris Genap (dua dan empat)

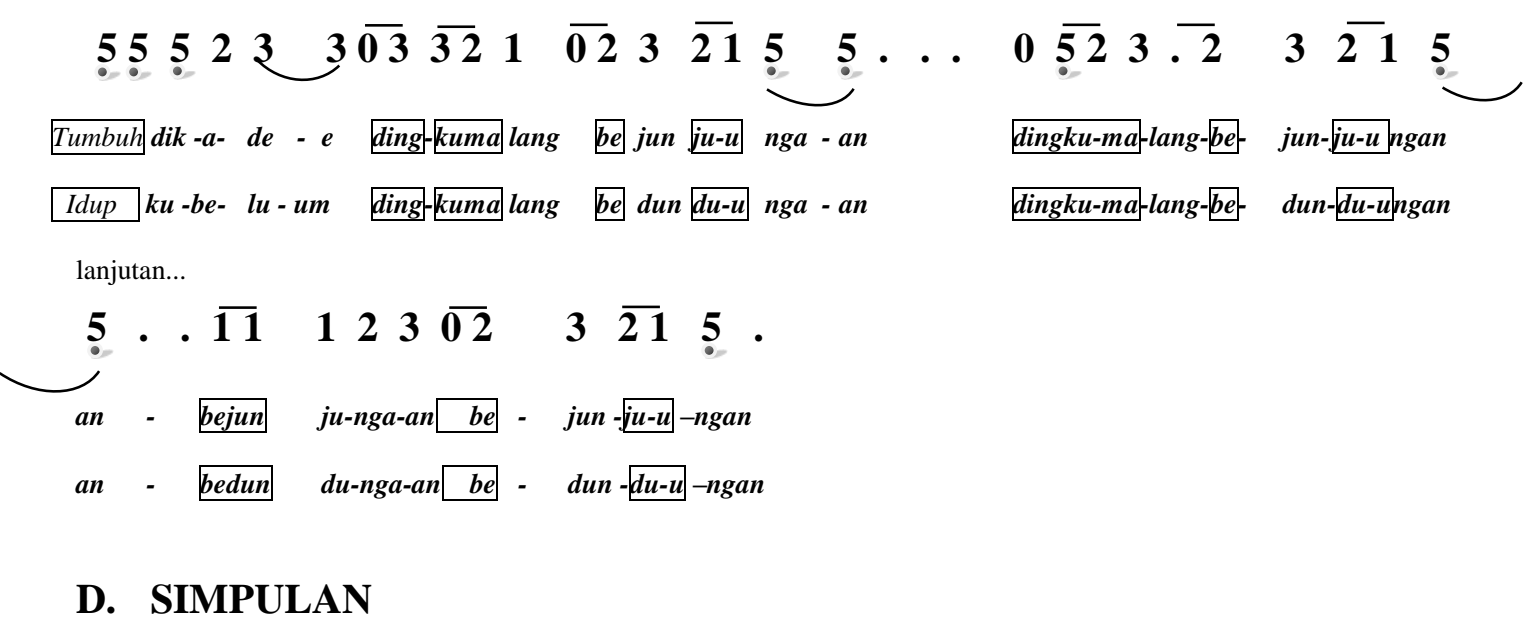

Setelah penelitian ini telah diuraikan, maka memperoleh hasil dengan susunan materi pembelajaran muatan lokal provinsi Sumatera Selatan. Adapun materi yang telah di susun adalah; (1) Teknik Menembangkan Seni Rejung, (2) Cara Pembawaan Seni Rejung, (3) Syair/pantun Seni Rejung, dan (4) Irama/lagu Seni Rejung. 


\section{DAFTAR PUSTAKA}

Abidin, Y. (2014). Desain Sistem Pembelajaran Dalam Konteks Kurikulum 2013. Cetakan Kesatu. Bandung: PT. Refika Aditama.

Fang, Liaw York. (2011). Sejarah Kesusastraan Melayu Klasik. Jakarta: Yayasan Pustaka Obor Indonesia.

Hidayatullah, Fadhilah. (2015). Pembelajaran Kesenian Rejung melalui Pendekatan Saintifik untuk Penanaman Nilai Budaya Lokal di Universitas PGRI Palembang. Jurnal Penelitian Pendidikan. Volume 15 Nomor 2: 8794. LPPM Universitas Pendidikan Indonesia.

Ahmad Kordin (67), Seniman Rejung dan Tokoh Masyarakat Semende Darat, Dusun Tanjung Bulan Kecamatan Pulau Beringin Kabupaten OKU Selatan.

Peraturan Gubernur Sumatera Selatan tentang materi muatan lokal di Sumatera Selatan, tahun 2015.

Prastowo, Andi. (2011). Metode Penelitian Kualitatif dalam Perspektif Rancangan Penelitian. Jogjakarta: Ar-ruzz Media.

Sudarmayanti, dkk. (2002). Metode Penelitian. Bandung: CV. Mandar Maju.

Sumardjo, Jakob. (2006). Estetika Paradoks. Bandung: Sunan Ambu Press. 